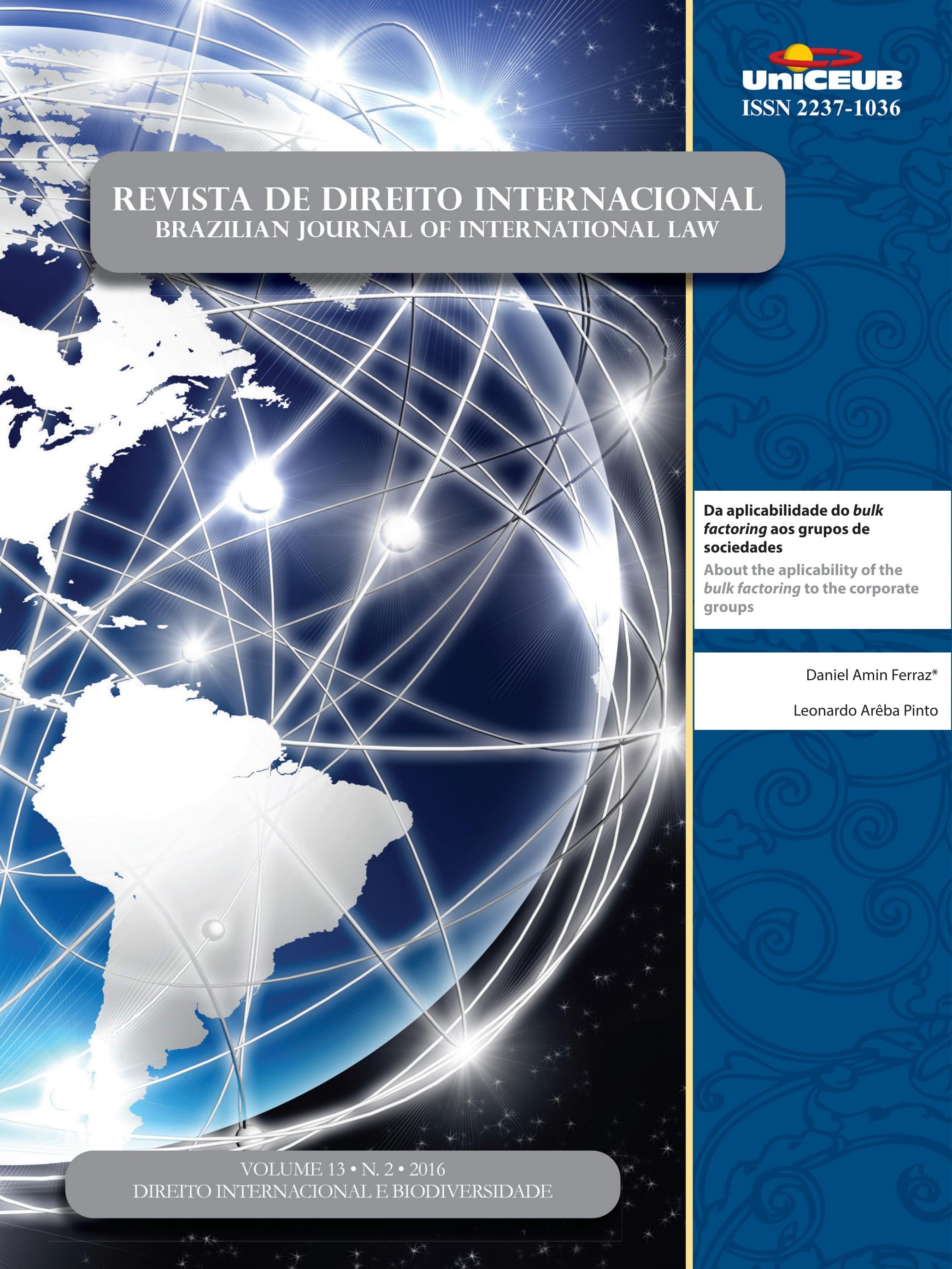




\section{Sumário}

CRÔNICAS DE DIREITO INTERNACIONAL PRIVADO 3 Gustavo Ferreira Ribeiro, Inez Lopes Matos Carneiro de Farias, Nadia de Araujo e Marcelo De Nardi

EDITORIAL 22

Márcia Dieguez Leuzinger e Solange Teles da Silva

IMPROVING THE EFFECTIVENESS OF LEGAL ARRANGEMENTS TO PROTECT BIODIVERSITY: AUSTRALIA AND BRAZIL .25

Paul Martin, Márcia Dieguez Leuzinger e Solange Teles da Silva

O RECONHECIMENTO DA DIGNIDADE DOS ELEMENTOS DA BIODIVERSIDADE COM BASE NO DIÁLOGO ENTRE O DIREITO INTERNACIONAL E O ORDENAMENTO JURÍDICO BRASILEIRO

Augusto César Leite de Resende

O REGIME INTERNACIONAL DO CLIMA E A PROTEÇÃO AOS “REFUgIADOS CLIMÁTICOS”: QUAIS DESAFIOS DA COP 21?

Ana Carolina Barbosa Pereira Matos e Tarin Cristino Frota Mont'Alverne

A anÁlise do MECANismo REdD+ COM Vistas À MitigaÇÃo dos EFEITOS DAS MUdANÇAS CLIMÁTICAS E À PROTEÇÃO DA DIVERSIDADE BIOLÓGICA FLORESTAL

Diogo Andreola Serraglio e Heline Sivini Ferreira

ECOLABELS DE EFICIÊNCIA ENERGÉtiCA E SUA CONSISTÊNCIA COM A DISCIPLINA DOS PPM's E PROVISÕES dOs Acordos GATT E TBT.

Cristiane Derani e Arthur Rodrigues Dalmarco

ANÁLISIS DEL ORDENAMIENTO JURÍDICO INTERNACIONAL SOBRE PROTECCIÓN DE LOS RECURSOS GENÉTICOS: DESAFIOS Y PERSPECTIVAS EN URUGUAY A PARTIR DE LA IMPLEMENTACIÓN DEL PROTOCOLO DE NAgOYA 115

Alina Celi 
LE RÉGIME INTERNATIONAL DE L'ACCÈS AUX RESSOURCES GÉNÉTIQUES AU PRISME DE L'ENTRÉE

en VIgUeUr du Protocole de NAgoya .............................................................. 131

Rodolpho Zahluth Bastos, Otávio Canto, Karine Galy e Isabelle Vestris

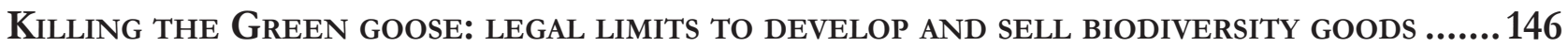
José Augusto Fontoura Costa e Liziane Paixão Silva Oliveira

VÍNCULO SUBSTANCIAL E AS BANDEIRAS DE CONVENIÊNCIA: CONSEQUÊNCIAS AMBIENTAIS DECORRENTES DOS NAVIOS COM REGISTROS ABERTOS ....................................................... 160

Marcos Edmar Ramos Alvares da Silva e André de Paiva Toledo

ANÁLISE DE CONTRATOS PÚblicos SOCIOAMBIENTAIS NO CENÁRIO PORTUGUÊS DE CRISE ECONÔ-

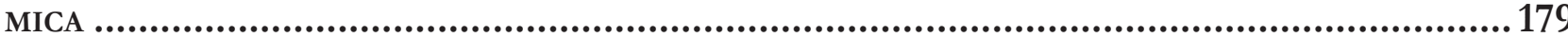

Alice Rocha da Silva e Matheus Passos Silva

A ORganizaÇão do TRATAdo DE COOPERAÇão AMAZÔNICA: UMA ANÁLISE CRÍTICA dAS RAZÕES POR TRÁS DA SUA CRIAÇÃO E EVOLUÇÃO

Paulo Henrique Faria Nunes

O uso de EXPERTS EM Controvérsias ambientais Perante a CorTe InTERnacional de JusTIÇA ........................................................................................................245

Lucas Carlos Lima

Os VIESES dA BIODIVERSIDAdE APRESENTAdos PELO CASO do PARQUE EÓlico DE BALd HiLls ......261 Natália Zampieri e Mariana Cabral

Mining CBD 275

Claire Lajaunie e Pierre Mazzega

Biotecnologia moderna, direito e o pensamento Abissal

Reichardt, F.V., Garavello, M. E. P. E., Molina, S.M.G. e Ballester, M. V. R.

Community Core Values como parâmetro de efetivação dos Princípios da Precaução e da Participação Popular em instrumentos de controle de projeto atividade de alta COMPLEXIDADE AMBIENTAL................................................................................... 314

Michelle Lucas Cardoso Balbino 
Discussões BIOTECNOLÓgICAS QUANTO AOS ORGANISMOS GENETICAMENTE MODIFICADOS NO ÂMBito da OMC: do contencioso ao acordo de vontades entre Argentina e União EuroPEIA

Gustavo Paschoal Oliveira

O Trans-Pacific Partnership Agreement e seus potenciais impactos para a regulação

DA BIODIVERSIDADE NO ÂMBITO TRANSNACIONAL..........................................................375

Mariana Yante Barrêto Pereira

AS ÁREAS PROTEGIDAS TRANSFRONTEIRIÇAS: REFLEXÕES CRÍTICAS ACERCA DE UM USO GEOPOLÍTICO DO DIREITO DA BIODIVERSIDADE.

Rabah Belaidi

O Que o caso Estados Unidos vs. Texas nos dirá sobre o direito de IMigração nos EsTADOS UNIDOS? 409

Danielle Anne Pamplona

Clóvis Beviláqua e a justiça internacional: entre o sim E o Não a Rui Barbosa.... .422 Paulo Emílio Vauthier Borges de Macedo

Possibilidade de delegação de atribuição para a Celebração de Tratados pela RepúbliCa Federativa do Brasil: análise do artigo 84, VIII c/c Parágrafo único da ConstituiÇão FEDERAL

Luciano Monti Favaro e Héctor Valverde Santana

Dignity, ubuntu, HUMANiTY AND AUTONOMOUS WEAPON SYSTEMS (AWS) DEBATE: AN AfRiCAN PERSPECTIVE 460

Thompson Chengeta

DiREITO INTERNACIONAL PRIVADO E O DIREITO TRANSNACIONAL: ENTRE A UNIFICAÇÃO E A ANARQUIA .503

André De Carvalho Ramos

A ilusória ausênCia do termo DépeÇage na JURisprudênCia brasileira de contratos INTERNACIONAIS

Gustavo Ferreira Ribeiro 
O EFEITO DIRETO DAS DIRETIVAS E OS DIREITOS FUNDAMENTAIS........................................535 Lucas Fonseca e Melo e José Levi Mello do Amaral Júnior

DA APLICABILIDADE DO BULK FACTORING AOS GRUPOS DE SOCIEDADES 565 Daniel Amin Ferraz e Leonardo Arêba Pinto

A Questão hermenêutica no direito das GENTES ................................................580 Inocêncio Mártires Coelho 


\title{
Da aplicabilidade do bulk factoring aos grupos de sociedades
}

\section{About the aplicability of the bulk factoring to the corporate groups}

\author{
Daniel Amin Ferraz ${ }^{* *}$ \\ Leonardo Arêba Pinto***
}

\section{Resumo}

O objeto do presente artigo é determinar como o Bulk Factoring seria instrumento jurídico apto a desenvolver os grupos de sociedades. Para tanto, em primeiro momento, pretende-se analisar os elementos fundamentais e distintivos do contrato de factoring ou fomento mercantil. Uma vez estabelecidas as premissas atinentes ao contrato de fomento mercantil, em segundo passo, pretende-se analisar a modalidade específica do Bulk. Factoring, demonstrando seus elementos distintivos, sua aplicabilidade e os benefícios advindos dessa aplicação. Em terceiro momento, após definição dos grupos de sociedades, será feita análise de quais fatores contribuem para o fortalecimento e expansão dos mencionados grupos. Por fim, pretende-se demonstrar que o Bulk. Factoring consiste em negócio jurídico de natureza mercantil que promove o fortalecimento dos grupos de sociedades.

PALAVRAS-CHAVE: Contratos comerciais. Bulk Factoring. Grupos de Sociedades.

* Autores convidados

** Possui mestrado em Direito Empresarial pela Universidade de Coimbra (1998) e doutorado em Aspectos Actuales del Derecho Internacional - Universidad de Valencia (2004). Professor da Universidade Federal de Juiz de Fora - MG (em processo de redistribuição). Professor do Mestrado/Doutorado do UniCeub, Brasília. Foi Diretor do Departamento de Cooperativismo e Associativismo - DENACOOP, do Ministério da Agricultura, Pecuária e Abastecimento, MAPA. Tem experiência na área de Direito, com ênfase em Direito Empresarial e Empresarial Internacional, atuando principalmente nos seguintes temas: globalização, grupos de sociedades, contratos internacionais, direito da concorrência e nova ordem internacional. E-mail: daniel.amin@afcadvogados.adv.br

*** Mestrando no Programa de Mestrado da Uniceub, Brasília. E-mail: leonardoarebaadv@ gmail.com

\section{Abstract}

The subject matter of this article is to determine how the Bulk. Factoring would be a legal instrument able do develop the corporate groups. In order to achieve such goal, in the first moment, it proposes to analyze the fundamental and distinctive elements inherent to the factoring contract agreement. Once established the preliminar elements regarding the factoring contract agreement, as a second step, it also proposes to analyze the specific modality of the Bulk Factoring, demonstrating its distinctive elements, its aplicability and the benefits that arise from its application In the third moment, after the legal definition of the corporate groups, an analysis will be made on wich factors contribute for the fortification and expansion of the later corporate groups. Lastly, it proposes to demonstrate that the Bulk. Factoring consists in a legal contract agreement that promotes the fortification of the corporate groups. 


\section{Aproximação da matéria}

A sociedade das finanças, que sucedeu à sociedade industrial, tem fins muito mais amplos e complexos, em virtude dos produtos financeiros que, muitas vezes, não podem ser facilmente compreendidos ${ }^{1}$.

No passado, o grande capital era mono-setorial, dedicando-se a um determinado setor da indústria, do comércio ou dos serviços. Hoje o capital migra, de setor a setor, com grande flexibilidade. Assim, os "pacotes acionários" de controle das grandes companhias passam de mão em mão, de investidor a investidor. A partir do final do século $\mathrm{XX}$, o novo equilíbrio das empresas industriais como empresas de grupo está caraterizado pela divisão das funções de direção estratégica. A sociedade se converte de sociedade industrial em pós-industrial, ou financeira ${ }^{2}$.

Neste contexto, novos instrumentos surgem em uma sociedade financeira. Assim, o presente artigo possui como objeto de estudo o Bulk Factoring e sua utilização como instrumento contratual voltado ao fortalecimento dos grupos de sociedades.

Poderia o factoring, em específico em sua modalidade Bulk Factoring, ser considerado instrumento contratual estratégico para o fortalecimento e expansão dos grupos de sociedades, dado que a atividade empresária busca, constantemente, se expandir?

O factoring é, majoritariamente, contrato celebrado por pequenas e médias empresas ${ }^{3}$, as quais buscam ob-

1 "É necessário definir a nova agenda de desenvolvimento, buscando um novo equilíbrio entre o mercado livre e o interesse público, entendidas as políticas públicas como todas as formas de ação organizadas na esteira de objetivos de interesses comuns, não somente ações estatais". FERRAZ, Daniel Amin. A concentração empresarial no contexto da economia internacional, em: FERRAZ, Daniel Amin. Direito Empresarial: marco jurídico de internacionalização das empresas brasileiras, Ed. CRV, Curitiba, 2012, p. 10.

2 GALGANO, Francesco. La globalizzazione nello specchio del diritto, Società editrice il Mulino, Bologna, 2005, p. 27.

3 As pequenas e médias empresas sempre foram uma preocupação no seio da União Europeia, recebendo tratamento diferenciado do direito comunitário. $\mathrm{O}$ mesmo ocorre porque, quando analisados os dados de produção empresária, mais de $99 \%$ (noventa e nove) por cento das empresas em território europeu são constituídas por PMEs, adotando-se o critério de possuírem até 500 empregados. Por outro lado, pelo mesmo critério do número de empregados, mais de $91 \%$ (noventa e um por cento) delas serão consideradas micro empresas, já que possuidoras de até 09 (nove) trabalhadores. Para aprofundamento nas definições de PMEs para o direito comunitário, que influenciou as diversas definições do Direito brasileiro, veja-se, entre muitos: PALMA, Augusta Ferreira. Das pequenas e ter capital de giro, promovendo a liquidação antecipada de recebíveis, voltados à operacionalização e exercício regular de suas atividades ${ }^{4}$. Com o presente estudo, busca-se demonstrar que o Bulk Factoring consiste em instrumento contratual utilizado por empresas de grande porte, integrantes de grupos de sociedades.

A relevância do presente tema de discussão é manifesta, dado que apresenta instrumento jurídico apto a otimizar a performance e a dinâmica dos grupos de sociedades, instrumento de concentração empresarial de terceira geração, sendo, hoje por hoje, o mais utilizado nas práticas negociais de grande porte ${ }^{5} /{ }^{6}$.

Ademais, o contrato de factoring se caracteriza como negócio empresarial e, em função disso, certos elementos típicos dos contratos mercantis são aplicáveis a essa espécie. Por isso, essencial traçar os moldes básicos dos contratos mercantis, a fim de que seus elementos distintivos restem consolidados.

O ordenamento jurídico brasileiro adota sistemática que teve amplo embasamento na legislação europeia moderna, que veio a substituir a então vigente doutrina consistente nos atos de comércio (que também tinha fundamento no direito europeu), eminentemente objetiva $^{7}$, para qualificar a atividade empresária como resul-

médias empresas: algumas questões (máxime, no Direito da Concorrência), Editora Almedina, Coimbra, 2001, p. 21 e ss.

4 BARBIER, Eduardo Antonio. Contratación bancaria, volume 2 Empresas. $2^{a}$ ed. acutalizada y ampliada. Ciudad de Buenos Aires, Editora Astrea, 2007, p. 379.

5 Em tópico específico, abaixo, será feita análise da natureza jurídica dos grupos de sociedades. Contudo, desde já, caracteriza-se o grupo de sociedades como um instrumento de concentração empresarial. Como tal, deve o mesmo ser regulado pelos organismos de controle das concentrações, caso, no Brasil do CADE. Todavia, para que tal regulação ocorra, dois elementos devem se fazer presentes, quais sejam, a definição de mercado relevante e de posição dominante. Para aprofundamento na matéria, ver: PEGO, José Paulo Fernandes Mariano. A posição dominante relativa no Direito da Concorrência, Editora Almedina, Coimbra, 2001, p. 23-54.

6 A globalização trouxe consigo a necessidade de adaptabilidade à expansão e internacionalização, que é natural, do capital. Assim, este buscou formas societárias mais flexíveis que lhe permitiriam cumprir com sua vocação expansionista, promovendo uma facilitação da concentração empresarial. Neste sentido, o grupo de sociedades constitui uma estrutura organizativa perfeita para cumprir tais fins. Isso porque permite o crescimento internacional da atividade empresária, com a devida concentração de capital, na diversidade formal, diversidade essa que explicaria seu amplo emprego na prática negocial. Neste sentido: PALAO MORENO, Guillermo. Os grupos de empresas multinacionales y el contrato individual de trabajo, Tirant lo Blnch, Valencia, 2000, p. 19.

7 Para definição da matéria comercial, três grandes teorias foram empregadas ao longo da evolução mercantilista do Direito. Assim, 
tado da organização dos elementos de empresa, ou, na

originariamente, a matéria comercial era definida pela teoria subjetiva. Por tal teoria, seria necessária a presença de um comerciante, no exercício habitual de sua atividade profissional para qualificação da matéria como mercantil. A grande dificuldade da teoria subjetiva era a necessidade da profissionalidade (entendida como registro ou arquivamento da Junta Comercial) e a habitualidade. Isso porque, poder-se-ia chegar ao absurdo de se entender que um comerciante sem registro não praticava matéria comercial. Por outro lado, a definição de habitualidade sempre foi questão sem solução. Qual seria a frequência necessária para a determinação de uma prática como habitual? Questões, como se vê, de difícil solução.

Pela dificuldade da caracterização da teoria subjetiva evoluiu o direito mercantil para a teoria objetiva de delimitação da matéria comercial. Por tal teoria (teoria objetiva), o elemento essencial para a determinação da matéria seria a prática dos atos de comércio. Assim, entendeu a doutrina, e depois o legislador pátrio, por intermédio do Regulamento 737/1850, que, determinados negócios jurídicos seriam sempre mercantis, independente de quem os praticasse. A lei os definiria sempre como mercantis, objetivamente, já que teriam o condão de gerar largos efeitos no mercado e deveria o Direito Especial (mercantil) se preocupar com sua regulação. Seriam exemplos clássicos dos atos de comércio objetivos a emissão e circulação dos títulos de crédito. Por seu turno, outros atos, ainda, seriam mercantis em virtude de sua natureza. Estes, denominados de atos de comércio subjetivos ou por natureza, teriam, em seu bojo, os elementos essências da mercantilidade, quais sejam, a circulabilidade (intenção de modificação de posse e/ou propriedade, e a especulação (intenção na obtenção de lucro). Para a doutrina os atos de comércio subjetivos necessitariam da presença de um comerciante na relação jurídica, mas não mais um comerciante registrado. Ou seja, neste ponto abandonada a profissionalidade. $\mathrm{O}$ contrato de compra e venda seria o ato de comércio subjetivo por excelência. Finalmente, presente ainda para a teoria objetiva os atos de comércio por conexão, entendidos como aqueles que, ainda que nem objetivamente, nem subjetivamente, mercantis, seriam assim classificados já que facilitariam a prática de outros atos de comércio. Portanto, seriam todos aqueles atos assessórios ou preparatórios da atividade perpetrados pelo empresário. Finalmente, a teoria empresarial nasce como o novo elemento para definição da matéria comercial. Passa a ser entendida a empresa como a organização dos fatores de produção, como posição de valor no mercado. Pela teoria empresarial passa a ser essencial a organização dos fatores de empresa para a qualificação da matéria. Seria ela uma volta ao subjetivismo, não mais focado na pessoa do empresário, mas sim na própria empresa, entendida como organização da atividade. Para entendimento da teoria subjetiva, veja-se: FERREIRA, Waldemar Martins. Tratado de Direito Mercantil Brasileiro, vl. 2, Livraria Editora Freitas Bastos, Rio de Janeiro, 1939, p. 24 e ss.; VAMPRÉ, Spencer. Tratado Elementar de Direito Commercial, vl.1, F. Briguiet \& Cia, Rio de Janeiro, 1922, p. 12 e ss., para quem o Direito Comercial seria aquele que "...estuda as regras applicaveis aos actos do commercio, e às pessoas que delle fazem profissão". Vê-se, da definição citada que a profissionalidade (registro) era requisito essencial para a delimitação da matéria comercial pela teoria subjetiva. Por seu turno, para aprofundamento na teoria objetiva, veja-se, entre muitos: MENDONÇA, João Xavier Carvalho de. Tratado de Direito Comercial Brasileiro, vl. 1, $6^{\text {a }}$ Edição, Livraria Freitas Bastos, Riode ed Janeiro, 1957, p. 419 e ss.; BORGES, João Eunápio. Curso de Direito Comercial Terrestre, vl.1, Editora Forense, Rio de Janeiro, 1959, p. 159 e ss. Para entendimento da teoria empresarial, veja-se, como fundamental: CARVALHO, Orlando de. Critério e Estrutura do Esta- concepção clássica, dos fatores de produção ${ }^{8}$.

Nessa linha, com o advento do Código Civil de 2002, consolidou-se a nova concepção do direito comercial no Brasil, baseada no conceito de empresa ${ }^{9}$. Assim, para a definição legal "Considera-se empresário quem exerce profissionalmente atividade econômica organizada para

belecimento Comercial, Coimbra Editora, Coimbra, Portugal, 1967. Veja-se, ainda: OLIVENCIA RUIZ, Manuel. Derecho mercantil y derecho de la empresa, em: JIMÉNEZ SÁNCHEZ, Guillermo J. Derecho mercantil I, Marcial Pons, Barcelona, 2010, p. 23 e ss.

8 "A crise do sistema objetivo deu origem aos novos contornos do direito mercantil. Desloca-se o centro das atenções do direito comercial, vale dizer, o ato dá lugar à atividade econômica. Unemse as ideias do ato de comércio e do comerciante numa realidade mais dinâmica, a da atividade econômica, isto é, o conjunto de atos destinados a um fim, a satisfação das necessidades do mercado geral de bens e serviços.

Mesmo antes de qualquer positivação de um novo regime, isto é, mesmo na vigência plena do Código Comercial de 1850, já houve um grande movimento no sentido de uma nova concepção do direito comercial no Brasil. Esse movimento foi extremamente influenciado pela nova concepção do direito comercial como direito das empresas, com a unificação do direito das obrigações promovido pelo Código Civil Italiano de 1942.

Modernamente urge uma nova concepção que qualifica o direito comercial como o direito das empresas, orientação maciçamente adotada na doutrina pátria, apesar de ainda existir alguma resistência. Nesta fase histórica, o direito comercial encontra sua justificação não na tutela do comerciante, mas na tutela do crédito e da circulação de bens e serviços, vale dizer, não são protegidos os agentes que exercem atividades econômica empresariais, mas a torrente de suas relações". TOMAZATTE, Marlon, Curso de direito empresarial: teoria geral e societário, volume 1. 6 ed. São Paulo: Atlas, 2014, p. 13.

9 Importa referir que para a teoria clássica do direito mercantil haveria uma clara distinção entre empresa, empresário e estabelecimento mercantil. Assim, a empresa era entendida como mera atividade, objeto de direito. Ademais, era a mesma qualificada como objeto de direito mercantil, equiparada à mercadoria, possuindo, por isso mesmo, valor intrínseco e podendo ser negociada de forma autônoma, independe de quaisquer outros bens, corpóreos ou incorpóreos. Interessante notar que quando o franqueador realiza contrato de franquia transfere para o franqueado parte de sua empresa, sem haver, obrigatoriamente, a transferência de quaisquer outros bens. Por seu turno, empresário é a pessoa, individual ou coletiva, registrada ou não (no caso do Direito brasileiro, na Junta Comercial), que exerce atividade empresária, ou seja, que exerce empresa. É sujeito de direito e, em nome de quem, adquire-se direitos, assumese obrigações. Finalmente, estabelecimento comercial, qualificado como objeto de direito, sendo um bem móvel, geralmente material, infungível, composto por bens materiais e imateriais, fungíveis e infungíveis, sempre móveis. O estabelecimento é o instrumento com o qual o empresário exerce a empresa.

Depois de todo o manifesto, sublinhe-se que, para a moderna teoria empresarial, não haveria distinção entre as ideias de empresa e empresário, havendo, tão somente, a preocupação com a organização dos elementos de empresa para a definição da matéria empresária, quais sejam, capital, trabalho e, modernamente, informação. 
a produção ou a circulação de bens ou de serviços"10.

Com isso, a atividade empresária, nos termos de nosso ordenamento jurídico, passou a contar com aspectos subjetivos e objetivos em sua definição. Subjetivamente, empresário é o indivíduo, pessoa física ou jurídica, que organiza as atividades de produção e/ou circulação de bens e serviços. Objetivamente, qualquer atividade que se enquadre como profissionalmente organizada, voltada à circulação ou à produção de bens ou serviços, com especulação, será considerada empresária.

Por outro lado, o contrato é instrumento necessário para que o empresário exerça sua atividade. Permite a instrumentalização da atividade empresária. Vale referir que, aqueles contratos praticados por empresários, quando do exercício de sua atividade, entendidos como elementos de empresa, serão considerados mercantis. Presente o elemento subjetivo (presença de empresários); ademais do elemento objetivo de delimitação da matéria (a prestação do contrato celebrado entre empresários deve estar voltada à atividade econômica profissionalmente organizada por eles, à circulação ou produção de bens ou serviços) ${ }^{11}$.

Constata-se, assim, que o contrato será configurado como mercantil quando dois empresários celebram negócio cuja prestação é voltada à atividade econômica, de produção ou circulação de produtos ou serviços, e profissionalmente organizada.

A classificação de um contrato como mercantil pretende determinar se a principiologia do Direito Comercial será a ele aplicável ${ }^{12}$. Logo, uma vez assim configu-

10 Art. 966 do Código Civil brasileiro.

11 Caso os mencionados aspectos não sejam cumpridos, pode-se incorrer na configuração de contrato com natureza jurídica diferenciada. Esse contrato poderia vir, inclusive, a ser considerado consumerista, desde que a posição de empresário de uma das partes desapareça, dando lugar ao receptor final de um produto ou serviço. BROSETA PONT, Manuel. Manual de derecho mercantil, décima edición, Editorial Tecnos, Madrid, 2000, p. 449.

12 Saliente-se que existente, hoje em dia, a dicotomia do Direito privado. Assim, ademais dos princípios próprios, possui o Direito empresarial sua normatização específica. Desta forma, regra geral, as normas empresariais referem-se aos chamados mecanismos jurídicos, entendidos como procedimentos complexos que se distanciam do direito civil, tais como as operações de fusão, cisão, incorporação de sociedades anônimas; os contratos e títulos de crédito complexos, tais como o leasing, o factoring, as cédulas de crédito. Por outro lado, existentes ainda as leis regulamentadoras da matéria empresária, verdadeiros "códigos", vez que praticamente funcionariam como um sistema jurídico autônomo, v.g., o sistema falimentar e de recuperação, a lei das sociedades por ações, o Código de Propriedade Industrial, etc. Finalmente, há que se falar na práxis mercantil, rado, um conjunto de características lhe será atribuído, determinando-se a aplicabilidade de normativa própria sobre a matéria ${ }^{13}$.

As características inerentes ao contrato mercantil, portanto, consistem na onerosidade, qual seja a busca de lucro pelos contratantes; a elasticidade; a rapidez; a simplicidade de regras; a internacionalidade; a não solenidade.

Por seu turno, o contrato de factoring, objeto do presente estudo, é mercantil, motivo pelo qual as construções até o momento realizadas se mostram indispensáveis.

Destarte, possível aduzir que o contrato de factoring não é especificamente regulado pela legislação brasileira. Tal normatização se dá de maneira esparsa. O que se tem é a positivação de diversos de seus institutos, mas não de sua integralidade, como se um contrato mercantil típico fosse.

A falta de regulação do contrato de factoring advém de 1988, ano no qual a Convenção sobre Factoring Internacional (de Ottawa) reuniu dezenove países para tratar e uniformizar a matéria. O Brasil, ao fim da Convenção, ratificou as assertivas sedimentadas sobre o factoring e o leasing, mas não se consagrou como signatário porque

não regulada legislativamente, mas constantes dos usos e costumes mercantis. Veja-se, neste sentido: BULGARELLI, Waldirio. Normas Jurídicas Empresariais, Editora Atlas, São Paulo, 1992, p.78 e ss.

13 "Se, em regra geral a obrigação é uma só, decorra de atos de natureza civil ou empresarial, inegável é que as resultantes dos atos empresariais sofrem a influência deles e, por isso mesmo, em determinados aspectos divergem das obrigações civis. Sabe-se que o Direito Comercial tem características próprias, que retratam justamente o dinamismo do comércio, em contraste com a posição conservadora, de certo modo estativa, dos atos de natureza civil. Assim, enquanto o Direito Civil é um direito tradicional, preso a antigas regras, de lenta evolução, o Direito Comercial, para atender às exigências do desenvolvimento do comércio, é um direito que se renova a cada instante, prescindindo, quando necessário, de fórmulas solenes, adaptando-se ao progresso e, de certa forma, procurando acompanhar as contingências econômicas dos diversos povos. E por que as relações comerciais exigem prontas soluções para fatos que surgem a cada momento o direito mercantil procura dar ao empresário maior elasticidade de ação, mais ampla liberdade, mais facilidade para que os casos surgidos sejam resolvidos com a rapidez que as transações empresariais requerem. Caracteriza-se, assim o Direito Comercial, como já anteriormente assinalamos, pela simplicidade, de suas fórmulas, pela internacionalidade de suas regras e institutos, pela rapidez de sua aplicação, pela elasticidade dos seus princípios e também pela onerosidade de suas operações. Neste sentido, distancia-se grandemente o Direito Comercial do Civil, em regra formalístico, nacional, lento, restrito”. MARTINS, Fran. Contratos e obrigações comerciais. $16^{\text {a }}$ ed. Rio de Janeiro, Forense, 2010, p. 10. 
o embaixador então presente não possuía poderes para confirmar o vínculo nacional à Convenção ${ }^{14}$.

Como não houve nenhuma ratificação posterior ao advento da Convenção de Ottawa, o Brasil não consta entre seus signatários. O que ocorre na prática é a harmonização informal dos ditames do factoring no Brasil com os princípios internacionais do mesmo contrato ${ }^{15}$.

Define-se de pronto o contrato de factoring como negócio jurídico pelo qual o empresário tido como faturizador adquire, mediante transferência de direitos, créditos devidos por terceiros, originariamente de titularidade do empresário faturizado. O faturizador passa a ser o titular do crédito recebido, e o faturizado recebe liquidação antecipada pelo crédito que transferiu ${ }^{16}$.

A partir do conceito de factoring, torna-se possível delinear quais elementos subjetivos integram esse negócio jurídico. O faturizador (ou fator) é necessariamente um empresário, que irá adquirir, pela cessão de crédito ou pelo endosso, os créditos de seu cliente, o faturizado ${ }^{17}$.

O outro elemento subjetivo desse contrato é o cliente da faturização, qual seja o faturizado. Como já suscitado, a tendência majoritária é que o faturizado seja

14 SOARES, Marcelo Negri. Contrato de factoring, Saraiva, São Paulo, 2010, p. 16.

15 Para o entendimento da internacionalização do contrato de factoring, veja-se, entre outros: RODRIGUEZ RODRIGO, Juliana. Contratos internacionales de factoring, em: CALVO CARAVACA, Alfonso Luis e CARRASCOSA GONZÁLEZ, Javier. Curso de Contratación Internacional, $2^{a}$ edición, Colex, Madrid, 2006, p. 369 e ss.

16 "O contrato de faturização ou factoring é aquele em que um empresário cede a outro os créditos, na totalidade ou em parte, de suas vendas a terceiros recebendo o primeiro do segundo o montante desses créditos, mediante o pagamento de uma remuneração". MARTINS, Fran. Contratos e obrigacōes comerciais. $16^{a}$ ed. Rio de Janeiro, Forense: 2010, p. 425.

17 Saliente-se que, no Brasil, existente a vedação para que bancos ou instituições financeiras exerçam a atividade negocial de factoring, fato que restringe tal negócio a empresas mercantis especializadas nessa linha de serviço. O mesmo ocorreria porque o negócio de faturização não teria natureza jurídica de mútuo (ou empréstimo bancário), mas sim de compra e venda. Em um negócio de fomento mercantil, o papel do faturizador seria, tão somente, o da aquisição do título, com a sua devida liquidação antecipada. Por outro lado, nos negócios bancários duas características seriam essenciais: a possiblidade de captação de recursos de terceiros no mercado; a incidência de taxa de juros sobre a operação. Tais características não estariam presentes nos negócios de factoring. No mesmo sentido: RIZZARDO, Arnaldo. Factoring, $2^{\mathrm{a}}$ edição, Editora Revista dos Tribunais, São Paulo, 2000, p. 96. Para um aprofundamento sobre os negócios bancários, veja-se: GONZÁLEZ NIEVES, Isabel Cristina. Estudios de Derecho y Economía, Editorial Heliasta, 2008, p. 124 e ss. empresa de pequeno ou médio porte, que busca antecipar seus recebíveis a fim de aumentar seu capital de giro e operacionalizar sua atividade econômica. Nota-se também que o faturizado necessariamente será um empresário, que busca auferir lucro na atividade que exerce nessa condição.

Exógeno aos elementos subjetivos do contrato de factoring se encontra o devedor, que também pode ser denominado como comprador, cliente ou devedor ${ }^{18}$. O devedor, logo, é aquele que celebrou negócio com o faturizado e, em função disso, assumiu a obrigação de pagar quantia em face a um serviço prestado ou a um produto fornecido ${ }^{19}$.

Importante frisar que o devedor não participa da negociação, ou seja, não consiste em um dos elementos subjetivos que compõem o contrato de factoring. No entanto, é afetado diretamente pela mudança do titular do crédito oriundo do factoring. Em face disso, a repercussão mais palpável da faturização para o terceiro devedor consiste na necessidade desse ser notificado da transferência do crédito.

Nos termos do artigo 292 do Código Civil de 2002, a obrigação do devedor pagar seu débito ao cessionário do crédito só se firmará com a notificação da transferência oriunda do factoring. Caso tal notificação não ocorra, o pagamento que o devedor fizer ao faturizado, ou a eventual cessionário anterior ao faturizador, restará plenamente válido, circunstância que frustraria a atividade e remuneração do faturizador.

O devedor também terá, segundo o artigo 294 do Código Civil de 2002, o direito de opor ao cessionário as exceções que lhe são inerentes, assim como as exceções oponíveis que veio a conhecer no momento em que a notificação da transferência de crédito se concretizou.

O contrato de faturização ou fomento mercantil possui natureza jurídica mercantil e, em função disso, as características previamente apresentadas, típicas desses contratos, são aplicáveis ao factoring. Logo, é o contra-

18 MARTINS, Fran. Contratos e obrigações comerciais. $16^{a}$ ed., Forense, Rio de Janeiro, 2010, p. 432.

19 A estrutura da relação creditória é decomposta em dois elementos distintos: a) o débito, entendido como o dever de prestar, a necessidade de observar determinado comportamento e; b) a responsabilidade, entendida como a sujeição dos bens do devedor ou de terceiros aos fins da execução. Neste sentido: VARELA, João de Matos Antunes. Das obrigações em geral, vol. I, $8^{a}$ edição, Almedina, Coimbra, 1994, p.147. 
to internacionalizado, oneroso, prima pela simplicidade em sua formação, é elástico e é rapidamente celebrado e operacionalizado, sendo negócio jurídico atípico no direito brasileiro, ainda que socialmente típico. É, ainda, negócio socialmente e juridicamente nominado ${ }^{20}$.

Embora o contrato de factoring tenha qualificação de negócio mercantil de financiamento (ainda que não praticado por Instituições Financeiras no Brasil), não é possível atribuir uma única prestação ou natureza jurídica à esse contrato.

Como já demonstrado, a compra e venda de crédito consiste em elemento inerente ao objeto do factoring. Assim, a simples venda de títulos de créditos por parte da faturizada à faturizadora efetivamente consiste numa espécie de financiamento, dado que tal tradição visa a antecipação de recebíveis originariamente datadas a termo. Tal operação, inegavelmente, adquire um caráter de técnica financeira por parte da faturizada ${ }^{21}$.

Contudo, esse não é o único objeto do factoring, dado que a remuneração do faturizador também se fundamenta nos serviços prestados ao faturizado. Além do ato de compra e venda de créditos por parte da faturizadora, essa ainda presta serviços de análise de risco ${ }^{22}$, cobrança, gestão financeira, ou qualquer outra espécie de serviço que advenha da autonomia da vontade das

20 Para um aprofundamento sobre a classificação dos negócios jurídicos como socialmente e juridicamente típicos e atípicos, nominados e inominados, veja-se: VASCONCELOS, Pedro Pais de. Contratos atípicos, coleção teses, Livraria Almedina, Coimbra, 1995, p. 207 e ss. Interessante, neste ponto, fazer uma distinção quanto à tipicidade dos contratos no Direito inglês. Assim, naquele direito, estranho à nossa herança ítalo-germânica de direito codificado, não haveria uma distinção entre contratos típicos e contratos atípicos. O mesmo se daria porque o regime jurídico dos contratos é único, denominado, habitualmente, de singular (Law of Contract). Assim, como teriam todos os contratos um regime jurídico único, não haveria a definição de contratos como típicos. Ademais, essa unidade regimental (marco regulatório único) é mantida independente da natureza jurídica das partes ou das relações jurídicas, não havendo, portanto, distinção, sempre naquele Direito, entre contratos civis e mercantis. Nesse sentido, veja-se: SÁNCHEZ LORENZO, Sixto A. El Derecho inglés y los contratos internacionales, Tirant lo Blanch, Valencia, 2013, p. 18.

21 “(...)Como técnica financeira, representa um financiamento da empresa faturizada, adquirindo o faturizador os créditos dessa, pagando-lhe e assumindo o risco com a cobrança e o não pagamento das contas, sem ter o direito de regresso contra o faturizado". MARTINS, Frans. Op. Cit., p. 435.

22 Em matéria de finanças, o risco seria entendido como a falta de certeza sobre a produção de um resultado determinado. Para aprofundamento sobre a caracterização financeira do risco, veja-se: LÓPEZ TILLI, Alejandro. Financiamiento de la empresa, Editorial Astrea, Buenos Aires, 2010, p. 16 e ss. partes.

Uma vez celebrado o contrato de factoring, o faturizador terá acesso à certeira de clientes e de créditos que a faturizada dispõe, optando por qual crédito efetivamente irá adquirir, em ato que antecipa o recebimento pelo faturizado. Desse procedimento, extrai-se que nem todos os créditos de titularidade da empresa cliente (faturizada) serão comprados pela faturizadora, mas tão somente aqueles que valham o risco de futura inadimplência dos emitentes, já que o mesmo (os risco de inadimplência dos emitentes) é, regra geral, assumido pelo faturizador ${ }^{23}$.

No tocante aos recebíveis da faturizada não adquiridos pelo faturizador, ainda existiria prestação de serviços consubstanciados na cobrança desses valores por parte da faturizadora ${ }^{24}$.

Portanto, para além do ato de compra e venda de recebíveis da faturizada, ainda existiria uma gama de serviços prestados pela faturizadora que não permitiriam o simples enquadramento do factoring como contrato de financiamento. Trata-se de negócio jurídico cuja natureza é mista ou complexa, dispondo de mais de um tipo de prestação contratual, prestações essas com naturezas e objetos diferentes ${ }^{25}$.

Uma vez assentado que o contrato de factoring é misto,

23 GOMES, Orlando. Contratos, $15^{\mathrm{a}}$ edição, Editora Forense, Rio de Janeiro, 1995, p. 468.

24 Estabelecido o contrato de faturização, as suas operações começam com a transferência, para o faturizador, de todas as contas do faturizado concernentes aos seus clientes. Fica, entretanto, o faturizador com o direito de escolher as contas que deseja adquirir, aprovando-as. Para isso, pode ele verificar, no arquivo do faturizado, tudo o que disser respeito aos clientes desse para poder escolher os que melhor lhe convêm. Tem, necessariamente, o faturizador seu próprio arquivo de informações a respeito dos clientes cujas contas lhe serão cedidas. A ele cabe, inclusive, orientar o faturizado na escolha dos clientes, para evitar futuros dissabores. Não são, assim, as contas de todos os clientes que serão cedidos pelo faturizado; igualmente, o faturizador pode se responsabilizar apenas por parte das contas de certos clientes, e só sobre essas partes incidindo as obrigações contratuais. Importa referir, ainda, que o factoring pode ser classificado como próprio ou impróprio. Por factoring próprio entende-se a modalidade através da qual o faturizador, adquirindo os títulos de titularidade do faturizado, assume o risco quanto ao cumprimento da obrigação originária pelo emitente. A contrário sensu, no factoring impróprio tal risco não é assumido pelo faturizador, mas, sim, continuaria de responsabilidade do faturizado. Veja-se, neste sentido: CHULIÁ VICENT, Eduardo e BELTRÁN ALANDETE, Teresa. Aspectos jurídicos de los contratos atípicos, Vl. I, segunda edición, JMB Editor, Barcelona, 1994, p. 28.

25 SOARES, Marcelo Negri. Contrato de factoring, Saraiva, São Paulo, 2010 , p. 24. 
válido também destacar as demais classificações que lhe são aplicáveis. Trata-se de contrato consensual, vez que não depende de tradição de bens ou da efetiva realização de serviço para que seja considerado válido (embora seja aconselhável que seja redigido e celebrado em forma física quando envolvidos valores substanciais); bilateral, pois gera obrigações tanto para faturizador quanto para faturizado; oneroso, dado que proporciona aferimento de lucro para ambas as partes contratantes, e; de execução sucessiva, pois vislumbra a possibilidade de pagar as prestações de forma continuada e ininterrupta.

Trata-se de contrato nominado, já que é mencionado por diversas vezes no ordenamento jurídico brasileiro, sendo, contudo, juridicamente atípico. É negócio obrigacional, pois diverge da forma contratual societária e estipula obrigações e direitos para os contratantes.

Tendo sido delineados os elementos fundamentais do contrato de factoring, cumpre analisar as especificidades do Bulk Factoring, e a sua relevância para o presente estudo.

\section{O bULK FACTORING COMO ESPÉCIE dO CONTRATO DE FACTORING}

O tópico anterior, voltado à ilustração dos contratos mercantis e à caracterização dos elementos fundamentais e distintivos do contrato de factoring, teve o intuito de sedimentar base conceitual para o estudo do Bulk Factoring.

O contrato de factoring, por ser mercantil e reconhecidamente atípico, encontra formas de aplicação tão numerosas quanto o ideário e a criatividade humana. As próprias demandas de mercado, as necessidades de gestão comercial e a criatividade dos empresários sempre serão motivo para a configuração de diferenciadas formas de celebração contratual, e o factoring não é uma exceção a esta circunstância.

Para fins de exemplificação, pode-se citar a modalidade do maturity factoring, na qual o cliente cobra ao vencimento do crédito, porque esta modalidade não cumpre função de financiamento, mas sim de colaboração, e não é uma atividade exclusiva da Sociedade Faturiza$\operatorname{dora}^{26}$.

26 MARTÍ HERNÁNDEZ, J. Contratación internacional, $2^{a}$ edición, tirant lo blllanch, Valéncia, 1999, p. 530.
Pode-se citar também o trustee factoring, modalidade na qual a interação entre faturizado e faturizadora é mais próxima do que numa modalidade de faturização na qual existe apenas a compra de recebíveis e a prestação de serviços, já que haveria a administração e direção das contas a receber daquela ${ }^{27}$.

Da mesma forma que as espécies citadas, o Bulk Factoring consiste numa aplicação específica da faturização, na qual o faturizador, o faturizado e o devedor integram o mesmo grupo de sociedades. Tal grupo econômico consiste em um grande aglomerado de empresas, motivo pelo qual o próprio termo “bulk”, vocábulo proveniente da língua inglesa, pode ser traduzida para o português como "massa”. Assim, a própria tradução do nomen juris do negócio sob análise acaba por explicitar que se trata de um contrato de faturização em massa.

A prestação do contrato de factoring, em sua modalidade Bulk, não é alterada substancialmente, mas tão somente enquadrada em um contexto que influencia as relações obrigacionais oriundas desse negócio jurídico. Confira-se o conceito do Bulk. factoring como sendo uma espécie já utilizada no Brasil...

“...por grandes conglomerados, em que empresas do mesmo grupo econômico fazem antecipação a seus fornecedores mediante ad valorem extremamente atrativo. Uma das empresas efetua compra a prazo e, após confirmada a entrega da mercadoria pelo fornecedor, que seria pago em parcelas, outra empresa do grupo da compradora das mercadorias no ramo de factoring - e devedora dos títulos - oferece e realiza a aquisição de seus próprios títulos, com risco praticamente nulo, uma vez que a devedora é do próprio grupo da empresa de factoring,"28.

O Bulk Factoring pressupõe a prestação do serviço de faturização em contexto integralmente endógeno a um grupo de sociedades, grupo este que usualmente possui dimensão econômica e jurídica de grande porte. Assim, todos os elementos subjetivos do factoring coexistem em um mesmo grupo de sociedades.

O fato de o Bulk Factoring ser utilizado no âmbito dos grupos de sociedades faz com que os elementos jurídicos inerentes a essa figura legal promovam efeitos diretos aos objetos da prestação devida tanto pelo faturizado como pelo faturizador. A estrutura jurídica e econômica dos grupos de sociedades promoveria, assim,

27 SOARES, Marcelo Negri. Contrato de factoring, Saraiva, São Paulo, 2010 , p. 38.

28 SOARES, Marcelo Negri. Op. Cit., p. 41. 
efeitos diretos ao contrato de factoring, passando, neste caso, a ser nominado como Bulk Factoring.

Da mesma forma, o grupo de sociedades também é afetado pela prestação de serviço de faturização em sua estrutura, objeto este que consiste, inclusive, no escopo do presente estudo.

Anteriormente à análise dos efeitos do Bulk Factoring para o grupo de sociedades, vale percorrer o caminho inverso, aduzindo que espécies de benefícios o grupo de sociedades pode garantir ao factoring.

\subsection{A relevância do crédito para a atividade empresária e os benefícios decorrentes do Bulk Factoring}

Aduzir que o aumento de confiança e a diminuição de riscos consistem em fatores derivados do Bulk. Factoring é o mesmo que dizer que esses fatores são proporcionados pela estrutura jurídica e econômica provida pelo grupo de sociedades. Ora, o Bulk Factoring nada mais é do que o próprio contrato de factoring no âmbito de um grupo de sociedades.

Ainda assim, considera-se mais acertado declarar que os supracitados fatores são decorrentes dessa modalidade específica de factoring, qual seja o Bulk Factoring.

Para que se compreenda a alegação de que o aumento da confiança efetivamente ocorre no Bulk Factoring, mostra-se necessário explanar de forma breve a importância do crédito para a operação da faturização, já que o aumento da confiança se vincula à maior segurança de adimplemento do crédito envolvido no factoring.

A existência do crédito representa elemento substancial do contrato de factoring. Neste contrato, o serviço prestado pela faturizadora, assim como a compra e venda de recebíveis, envolve de forma inexorável o crédito. Ora, a parte faturizadora avalia os riscos de determinados créditos, os cobra, sendo usual também que realize a compra de recebíveis originariamente de titularidade da faturizada.

Além de representar um dos elementos substanciais do contrato de factoring, o crédito também representa um dos pilares do direito empresarial ${ }^{29}$. O crédito é, claramente, pilar que demanda essencial e ininterrupta

29 TOMAZATTE, Marlon, Curso de direito empresarial: titulos de crédito, volume 2., 6 ed., Atlas, São Paulo, 2014, p. 1. atenção do empresário e do ordenamento jurídico, dada a sua relevância para a atividade mercantil.

É constituído de dois elementos, quais sejam a confiança e o tempo. A relação jurídica negocial sempre envolverá o elemento tempo, tendo em vista que a prestação ou entrega de um bem ou serviço, seguido de sua contraprestação, envolve o decurso de prazo. A confiança está atrelada ao tempo, e sedimenta a capacidade objetiva de o devedor satisfazer o crédito, e o aspecto subjetivo do crédito, que envolve a convicção moral do contratante de que o negócio que se celebrou será bem-sucedido ${ }^{30}$.

Claramente, a confiança e o crédito são elementos indissociáveis, e são determinantes para a regular celebração e operacionalização de contratos mercantis. Por muitas vezes, a própria segurança do crédito repercute de forma estrondosa em um negócio jurídico, e quanto maior a segurança e rapidez, maior é a possibilidade de êxito no negócio jurídico, com seu devido cumprimento voluntário ${ }^{31}$.

\subsection{O aumento da confiança e a diminuição de riscos como fatores inerentes ao Bulk Factoring}

A alegação de que o aumento da confiança e a diminuição dos riscos são fatores inerentes ao Bulk Factoring é intimamente associada ao conceito de crédito aqui firmado.

O que garante a maior segurança do crédito, com consequente diminuição de risco na operação do Bulk Factoring é o fato de que todos os elementos subjetivos da faturização integrarem o mesmo grupo de sociedades. A princípio, pressupõe-se que o vínculo econômico e jurídico das sociedades do grupo valora justamente a confiança existente entre seus membros, e o planejamento econômico unitário geralmente é pressuposto para tais conglomerados.

Assim, o crédito a ser obtido pelo faturizador passa a se constituir como uma operação de menor risco, dado que o inadimplemento possui menor chance de ocorrer. Isso também diminui o valor do serviço a ser prestado pelo faturizador, pois a análise de risco, a cobrança por

30 SOARES, Marcelo Negri. Op. Cit., p. 3.

31 FERRAZ, Daniel Amin. Dos contratos internacionais do comércio: regime geral, em: FERRAZ, Daniel Amin. Contratação internacional: algumas espécies de contratos mercantis, Editora CRV, Curitiba, 2015, p. 32-34. 
intermédio de mandato e qualquer outra diligência que consista em gestão financeira se tornam menos onerosas, tanto para o faturizado como para o faturizador. $\mathrm{O}$ deságio sobre o valor de face do título, em virtude da liquidação antecipada, assim como dos serviços prestados pelo faturizador diminui, e a faturizada consegue antecipar maior número de recebíveis.

Logo, todas as transações derivadas do Bulk Factoring são amplamente impulsionadas pelo incentivo garantido ao crédito envolvido em suas transações, dado que o risco de inadimplemento desse crédito diminui, e a confiança dos elementos contratuais subjetivos da faturização aumenta consideravelmente.

Com isso, a fim de se compreender neste momento os efeitos do Bulk Factoring em relação ao grupo de sociedades, vale esmiuçar seus elementos fundamentais, e delinear como o contrato em análise impulsiona também a dinâmica do grupo.

\section{Os beNEFí́cios deRIVAdos da CELEBRAÇÃo do CONTRATO DE BULK FACTORING PARA OS GRUPOS DE SOCIEDADES}

Quais seriam os benefícios para os grupos de sociedades em virtude da adoção, pelo próprio grupo, da prática do contrato de Bulk Factoring? Estes eventuais ganhos ocorreriam, tão somente, nas relações intragrupo, ou gerariam efeitos, ainda, para as relações dos mesmos com terceiros, extragrupo?

$\mathrm{Na}$ tentativa de responder a tais indagações é que se faz, a seguir, uma aproximação às definições e análises jurídicas do instrumento de concentração do grupo de sociedades.

\subsection{Os conceitos jurídicos aplicáveis aos grupos de sociedades}

Os grupos de sociedades representam uma terceira fase de uma escala evolutiva das estruturas empresariais. Em primeira fase, o empresário se organizava de forma pessoal, e os aparatos voltados à produção ou prestação de serviços tramitam em torno à figura pessoal do comerciante. Tratava-se do embrião da estrutura mercantil atomística, fundada na atuação individual na qual todos os ônus, responsabilidades e riscos da atividade realiza- da eram atribuídos a essa figura pessoal ${ }^{32}$.

Em segunda fase, o empresário passou a ser personificado pela sociedade comercial. A sociedade comercial, constituída na forma de pessoa jurídica, passou a polarizar a titularidade da atividade econômica outrora exercida pelo comerciante individual, desassociando a responsabilidade de tais atividades da figura da pessoa física.

Nessa fase, a atividade comercial ainda tramitava em torno da figura atomística da empresa, no momento constituída por sociedade empresária. A sedimentação da atividade comercial em torno da sociedade empresária ocorreu de forma natural e em progressão temporal, já que os sócios gestores das sociedades empresárias tiveram que se adaptar com a dimensão, tanto administrativa quanto econômica, das sociedades ${ }^{33}$.

Pode-se afirmar que o comércio internacional vislumbra a ascensão e fortalecimento da terceira fase da atividade empresária, que se consubstancia nos grupos de sociedades. Por intermédio dos instrumentos de concentração, as empresas societárias iniciaram um processo de aproximação e colaboração em suas atividades, decretando a substituição progressiva da estrutura de comércio atomizada pela molecular ${ }^{34}$.

A despeito do comércio internacional vislumbrar a consolidação dos grupos de sociedades como estrutura jurídica determinante, os ordenamentos jurídicos nacio-

32 Há que salientar que na fase atomística o Direito também regulou a atividade. Assim, é neste momento que se cria toda a teoria geral do direito comercial, com a devida qualificação do empresário individual, da matéria comercial, do estabelecimento mercantil, dos auxiliares para o exercício do comércio, dos princípios do Direito mercantil.

33 A esta segunda fase de evolução da matéria empresária corresponde uma segunda fase de evolução do Direito. Assim, na medida em que as relações deixam de ser individuais, não mais praticadas pelo comerciante individual, e passam a ser desenvolvidas pelo empresário coletivo, sociedade mercantil, nasce o Direito do empresário coletivo, ou, em outras palavras, o Direito societário. Assim, outros elementos tão relevantes para a atividade empresária passam a ter regulação própria, tais como a definição de capital societário (capital social, capital patrimonial, capital inicial, capital de giro); personalidade jurídica; registro; nome comercial; tipos societários, com a classificação das mesmas em dois grandes grupos (sociedades de pessoas e sociedades de capitais); dissídios societários; etc.

34 Assim, haveria uma substituição da atuação do empresário individual (pessoa física) pelo empresário coletivo (pessoa jurídica) e, finalmente, deste (empresário coletivo), pela constituição de grupos de sociedades, ou seja, "sociedades de sociedades". Veja-se: ANTUNES, José A. Engrácia. Os grupos de sociedades - estrutura e organização jurídica da empresa plurissocietária. Editora Almedina, Coimbra,1993, p. 14. 
nais não têm acompanhado o ritmo de crescimento que a terceira fase da atividade empresária apresenta. Assim, O Brasil, ao lado de Alemanha, Portugal e Hungria, é, hoje em dia, dos poucos países que tem regulação própria sobre a matéria ${ }^{35}$.

Os grupos de sociedades consistem em temática extremamente densa e abrangente. Assim, seriam eles entendidos, em um sentido próprio como...

“...todo o conjunto mais ou menos vasto de sociedades comerciais que, conservando embora as respectivas personalidades jurídicas próprias e distintas, se encontram subordinadas a uma direção econômica unitária e comum". ${ }^{36}$

Dessa definição, depreende-se que, em suma, dois elementos ou características fundamentais permitem definir o grupo de sociedades. O primeiro elemento peculiar ao grupo de sociedade é a independência jurídica entre os seus integrantes.

Assim, pessoas jurídicas ou sociedades que integram o grupo são autônomas juridicamente, podendo o instrumento de sua constituição ser contratual obrigacional ou contratual/estatutária societária ${ }^{37}$. Tal característica é compreensível, uma vez que para a constituição do grupo é necessária a existência de unidades jurídicas

35 Em nosso meio, a matéria dos grupos de sociedades, em capítulo próprio, pela Lei 6.404, de 15 de dezembro de 1976, nossa lei das sociedades anônimas. Ver artigos 265 à 277 da lei.

36 ANTUNES, José A. Engrácia. Os grupos de sociedades - estrutura e organização jurídica da empresa plurissocietária. Editora Almedina, Coimbra, 1993, p. 24.

37 O negócio jurídico, quanto a sua formação, pode ser classificado em obrigacional ou societário. O negócio obrigacional, por sua vez, se subdivide em negócio bilateral (vontades opostas que, pelo consenso, deverão estar consubstanciadas no negócio jurídico), ou negócio complexo (vontades paralelas, consubstanciadas no negócio jurídico, nascendo uma vontade única). Assim, o negócio obrigacional bilateral por excelência será a compra e venda. Por seu turno, o negócio complexo determinante será a franquia. Já com relação aos negócios societários uma subdivisão também se apresenta. Assim, o negócio de constituição das sociedades empresárias, com exceção da SA (sociedade anônima), serão negócios societários plurilaterais (entendidos como aqueles em que existem vontades paralelas, consubstanciadas no negócio jurídico, nascendo a busca de um objetivo comum - affetio societtatis, mas com um conflito latente entre as partes, no seio mesmo da sociedade. Por outro lado, o negócio de constituição da SA é também ele um negócio societário, porém não plurilateral mas sim estatutário. Assim o é porque entende-se que o legislador determinou, pela lei, um estatuto mínimo que deve ser seguido pelas partes quando da constituição de uma SA. Pois bem, são negócios contratuais tanto a os negócios bilaterais, como os negócios complexos, ou, como ainda, os negócios plurilaterais. A distinção entre eles é que os dois primeiros (bilaterais e complexos) são contratuais obrigacionais; o segundo (plurilateral) é negócio contratual, contudo societário (e não obrigacional). autônomas, que efetivamente se aglomeram com observância ao conceito de concentração secundária, e não de concentração primária. Esta espécie de concentração pressupõe o desaparecimento das sociedades individuais, característica que não se coaduna com a pluralidade típica da concentração secundária ${ }^{38}$.

O segundo elemento que permite distinguir o grupo de sociedades dos demais instrumentos de concentração empresarial é a unidade de direção econômica que as entidades componentes dessa estrutura adotam. A despeito das sociedades se constituírem em unidades jurídicas autônomas, a unidade econômica insurge como elemento unificador principal dos componentes do grupo, orientando a atuação dessas entidades à uma unicidade típica ${ }^{39}$.

38 O grupo de sociedades é, hoje em dia, o instrumento, por excelência, de organização da empresa transnacional. Técnica jurídica apurada pode fundamentar-se em três modalidades distintas, a saber: grupo de sociedades de base societária; grupo de sociedades de base contratual; grupo de sociedades de base pessoal. Por grupo de sociedades de base societária entende-se a organização do capital que permitirá coparticipação societária, determinante de um sistema de controle que gere o exercício do poder de gestão de uma sociedade, a sociedade mãe, sobre outros entes societários, as sociedades filhas. Importa ressaltar que nessa modalidade de grupo (de base societária) o instrumento de participação, constituído entre os membros do grupo, terá natureza jurídica de negócio societário, em sua classificação de negócio jurídico plurilateral (se entre sociedades limitadas) ou estatutário (se entre sociedades anônimas). Por outro lado, para a constituição de um grupo de sociedades de base contratual, não há que se falar em coparticipação societária, mas, tão somente, na realização de negócios jurídicos de natureza obrigacional. Assim, em um grupo de sociedades de base contratual, três são os elementos essenciais caracterizadores do grupo, quais sejam: a existência de uma relação obrigacional, objeto de contrato (geralmente negócio jurídico complexo), entre as partes; o poder de direção e controle derivado de tal contrato, em favor de uma das partes e em detrimento dos demais entes societários e; a dependência econômica, também decorrente do desenvolvimento da atividade do grupo. Claro está, portanto, que para a caracterização do grupo de sociedades de base contratual será fundamental a existência de relações jurídicas contratuais, obrigacionais, entre os membros do grupo, e que tais relações tenham o condão de gerar poder de direção e controle e dependência econômica. Assim, em sua classificação, o grupo de sociedades possui natureza múltipla, já que caracterizado como negócio jurídico societário (grupo de base societária) ou negócio jurídico obrigacional (grupo de base contratual). FERRAZ, Daniel Amin. Grupo de sociedades: instrumento jurídico de Organização da empresa plurissocietária, in: Revista de Direito Internacional, Volume 12, no 2, 2014, Brasília, p. 497 e ss.

39 Existem duas acepções fundamentais de grupo de sociedades. 1) Assim, em um sentido estrito ou próprio, entende-se por grupos de sociedades todo conjunto, mais ou menos amplo de sociedades mercantis que, conservando suas respectivas personalidades jurídicas, encontram-se subordinadas a uma direção econômica unitária e comum. As especificidades do fenômeno do grupo são, portanto, as seguintes: a) Sob o ponto de vista econômico, o grupo consti- 
A unidade de direção econômica do grupo de sociedades sobreposta à gestão estratégica e econômica de cada sociedade individual representa o elemento característico do grupo de sociedades, mesmo em sua vertente contratual/obrigacional. Se o vínculo não é necessariamente jurídico societário, ele será, certamente, econômico.

Diversas benesses advêm da estrutura do grupo de sociedades e da consequente unidade econômica derivada desse instituto jurídico. A compreensão da dinâmica e dessas alegadas benesses inerentes à organização das sociedades em grupo é essencial para o escopo deste estudo, que pretende demonstrar que o Bulk. Factoring consiste em instrumento contratual que impulsiona os elementos que incentivam a concentração de sociedades individuais e autônomas em grupos.

Primeiramente, pode-se apontar as vantagens econômicas advindas do grupo de sociedades. A existência de uma política econômica unitária e convergente no âmbito do grupo de sociedades permite que seus integrantes harmonizem, quase integralmente, as transações comerciais que realizam entre si. Com tal harmonia, pode-se implementar operações econômicas de integração vertical, que permitem a uma empresa de

tuiu uma nova e revolucionária forma de organização da atividade econômica moderna. Ao contrário da empresa tradicional, que se caracterizava por estruturar-se como uma empresa unissocietária, a empresa de grupo se constitui como uma unidade econômica plurissocietária, também chamada de empresa articulada. b) Por outro lado, sob a perspectiva jurídica, a especificidade do grupo de sociedades radica na oposição latente existente entre a situação de direito (pluralidade jurídica dos entes societários autônomos) e a situação de fato (unidade de atuação econômica, sob um poder de decisão central). Dessa forma, os elementos definidores do conceito do grupo de sociedades são a independência jurídica das sociedades agrupadas, assim como a dependência econômica de todas (sociedades fi liais) em relação a uma delas (sociedade matriz). 2) Em uma acepção ampla ou imprópria, a expressão grupo de sociedades (Konzern, Groupe de Siciétés, Group of Companies, Gruppo di Società), vem sendo utilizada como termo de referência para o setor da realidade societária que encontra no controle intersocietário e nas relações de coligação entre sociedades seu centro de gravidade. O direito tradicional das sociedades tem por objetivo a disciplina de constituição, organização e vida da sociedade comercial como entidade estática e isolada. Por sua vez, um direito de grupos de sociedades teria como objeto o estudo e a disciplina da constituição, organização e funcionamento da sociedade como entidade dinâmica e cooperativa. Nesse sentido, se poderia dizer que tal direito surgiria como uma espécie de metadireito das sociedades, de direito de sociedade das sociedades, ou ainda, de um direito das sociedades de segundo grau. FERRAZ, Daniel Amin. O grupo de sociedades: mecanismo de inserção da empresa transnacional na nova ordem econômica internacional, in: Revista de Direito Internacional, Brasília, v.9, n.1, p.15-25, jan./jun. 2012. grande porte do grupo, geralmente a sociedade-mãe, garantir o menor custo em todas as fases de industrialização e elaboração de seu produto ${ }^{40}$.

Fala-se também da possibilidade de implementação de uma integração horizontal, que por sua vez permite a redução de custos fixos relativos a determinado setor industrial e comercial, e também permite o aumento de poder de mercado nesse mesmo setor econômico ${ }^{41}$.

Importa referir, ainda, que a estrutura do grupo de sociedades permite que seus integrantes internalizem o mercado, diminuindo riscos de negociação com ele-

40 A caracterização de participação no capital como instrumento de domínio dependerá não somente de elementos quantitativos, mas também de elementos qualitativos. Assim, poderá haver uma participação que, ainda que majoritária, não caracterize domínio e, portanto, poder de direção e controle. O mesmo poderá ocorrer, por exemplo, por fatores determinantes da divergência, seja estatutária ou legal, entre participação e voto. Por outro lado, mesmo que o capital seja minoriatário, poderá ser qualificado como suficiente para determinar relações de domínio, derivada de "circusntancialismos específicos de natureza vária (legais, estatutárias, contratuais, fáctico)", permitindo ao sócio minoritário impor sua vontade à vontade social. Nesse sentido: ANTUNES, José A. Engrácia. Participações qualificadas e domínio conjunto, Publicações Universidade Católica, Porto, Portugal, 2000, p. 56 e ss. Ver, ainda: ABREU, J. M. Coutinho de; MARTINS, Alexandre Soveral. Grupos de sociedades: aquisições tendentes ao domínio total, Editora Almedina, Coimbra, 2003, p. 56 e ss; OSÓRIO, José Diogo Horta. Da tomada do controlo de sociedades (takeovers) por leveraged buy-out e sua harmonização com o Direito Português, Editora Almedina, Coimbra, 2001, p. 13 e ss. Outra figura interessante são as OPA, Ofertas Públicas de Aquisição. A primeira manifestação desta figura jurídica parece ter surgido no Direito Inglês, por intermédio das "compulsory purchase", reguladas no Companies Act de 1948. Por tal regulação, de uma sociedade adquire a participação de $90 \%$ ou mais do capital de outra sociedade, os sócios minoritários são obrigados a respeitar o instrumento de aquisição, podendo ser, inclusive, a transmitir suas ações à sociedade adquirente. Para aprofundar nessa análise, veja-se, entre outros: ANTUNES, José A. Engrácia. A aquisição tendente ao domínio total, Coimbra Editora, Coimbra, 2001, p. 40 e ss.

41 Quanto as formas de concentração, as mesmas se dividem em concentração vertical, horizontal e conglomerada. A concentração vertical se caracterizaria pela complementariedade dos elos da cadeia de suprimentos. Assim, haveria uma complementação entre produção, indústria e distribuição por intermédio dos grupos de sociedades. Por seu turno, concentração horizontal seria aquela dada entre concorrentes, em um mesmo setor de atividades, e o mesmo elo da cadeia de suprimentos. Finalmente, a concentração diz-se conglomerada quando praticada entre agentes de mercado que atuem em diferentes segmentos e sem nenhuma complementação. Para aprofundamento da matéria, veja, entre muitos: Ferraz, Daniel Amin. Acordos horizontais, acordos verticais e a jurisprudência norte-americana e europeia sobre a matéria. Revista de Direito Internacional, Brasília, v. 9, n. 2, p. 149-160, jul./dez. 2012; FERRAZ, Daniel Amin. La competência en el marco de los acuerdos horizontales y verticales: un análisis comparado de la UE, los EE.UU., Mercosur y Brasil, em: Papeles del Centro de Investigaciones, Universidad Nacional del Litoral, Santa Fé, Argentina, 2012, p. 9 e ss. 
mentos externos, e possibilitando a formação de uma hierarquia interna que preveja o funcionamento unitário e coeso das operações mercantis intra-grupo.

Pode-se ainda destacar os benefícios de natureza financeira. A estrutura do grupo de sociedades possibilita que um investimento inicial reduzido acabe por gerar acesso a uma massa de capital mais relevante, dada a eventual participação de uma sociedade nos proventos de outras. As vantagens financeiras eventualmente alcançadas pelos integrantes do grupo de sociedades, todavia, dependem de forma substancial do arranjo jurídico e econômico adotado pelo grupo. O fato é que a existência de uma única direção econômica no âmbito do grupo de sociedades acaba por demandar gestão financeira sofisticada, harmonizada com essa unicidade econômica.

As vantagens derivadas do grupo de sociedades residem, em suma, da autonomia jurídica que cada sociedade possui, possibilitando a assunção de obrigações de natureza diversificada, e permitindo maior controle das relações tributárias e trabalhistas de cada uma das empresas inseridas na estrutura do grupo de sociedades ${ }^{42}$.

\subsection{O Bulk Factoring como instrumento fortalecedor dos grupos de sociedades}

A análise dos institutos e fundamentos jurídicos e econômicos desenvolvidos e explanados neste estudo apontam que o Bulk Factoring consiste em contrato empresarial que fortalece a estrutura dos grupos de sociedades.

Um dos principais objetos da prestação de serviços no Bulk Factoring é a antecipação de recebíveis pelo faturizador ao faturizado. O faturizador compra os créditos de seu cliente que apresentam menor risco de inadimplência, e promove a cobrança de créditos cuja titularidade não pode assumir, dado que não obtidos ou transferidos. Além desses, presta outros serviços vinculados ao crédito.

42 Claro está que, em virtude dos elevados benefícios que traz a forma de organização dos grupos de sociedade são os mesmos, hoje em dia, frequentemente praticados. Contudo, evidente também que podem, com frequência, promover substancial diminuição da concorrência no mercado. Ademais, quando o controle passa pelo exercício da concentração financeira, havendo um controle financeiro unitário, os riscos à concorrência são ainda mais agravados. Veja-se, neste sentido: ANTUNES, José A. Engrácia. A supervisão consolidada dos grupos financeiros, Publicações Universidade Católica, Porto, Portugal, 2000, p. 19 e ss.
Ao passo que a estrutura do grupo de sociedades facilita a prestação de serviços e compra de créditos das empresas faturizadoras, o Bulk Factoring impulsiona as vantagens que advêm da concentração secundária.

Como apontado, a internalização do mercado é uma das benesses econômicas advindas do grupo de sociedade, e o Bulk Factoring, por envolver como partes os elementos subjetivos de um mesmo grupo, incentiva a realização de transações intra-grupos. Os riscos nestas transações serão menores, e a confiança e o tempo necessários para sua configuração também.

Por um lado, o faturizado, podendo esse ser a própria sociedade mãe, antecipa seus recebíveis e garante a liquidez do seu capital de giro, e passa a ter seus créditos e planejamentos financeiros tutelados pela empresa faturizadora. Por outro lado, a devedora cumpre a sua obrigação, e se adequa ao plano de direção econômica unitária própria do grupo de sociedades.

$\mathrm{O}$ aprimoramento da unicidade econômica e financeira do grupo de sociedades consiste em pilar que justificou a própria concentração secundária de sociedades empresárias, sendo que um impulso desses fatores contribui para o desenvolvimento do grupo como um todo. A atuação individual da faturizadora, nesse sentido, passa a ter repercussão molecular e não somente atomizada, dado que os benefícios oriundos de sua atuação repercutem para todo o grupo.

Importante ressaltar que o serviço da faturizadora, nessa hipótese, não deve se limitar à sociedade mãe, podendo ser estendido às sociedades integrantes do grupo. A prestação do objeto do factoring, dessa forma, acabará por estender a unicidade na gestão financeira e econômica às suas clientes, alcançando os objetivos próprios da estrutura de grupo de sociedades, quais sejam a hierarquização do grupo, a internalização de mercado e a unicidade na direção econômica do grupo.

Vale observar que tal aplicação do Bulk Factoring se coaduna com seu nomen juris (factoring de massa), e se apresenta como exceção à celebração de factoring com pequenas e médias empresas.

Além disso, a antecipação de recebíveis, típica da atividade de faturização, aumentará a liquidez do crédito no âmbito do grupo de sociedades e a velocidade com que as transações ocorrerão dentro do grupo.

Desta feita, as principais vantagens econômicas e financeiras que as sociedades individuais buscam ao inte- 
grar um grupo de sociedades serão potencializadas pela celebração do contrato do Bulk Factoring.

\section{Considerações finais}

O Bulk Factoring consiste em instrumento jurídico contratual obrigacional (empresarial) cuja celebração contribuiu para a potencialização das características e benefícios dos grupos de sociedades, e para seu consequentemente desenvolvimento.

Os serviços prestados pela faturizadora no Bulk Factoring contribuem para a centralização da política econômica e financeira das empresas integrantes do grupo de sociedades, e também permitem a maior liquidez e rapidez da circulação de crédito nesse âmbito, por intermédio da antecipação de recebíveis.

Finalmente, trata-se de técnica jurídica que garante benefícios tanto à parte faturizadora quanto à parte faturizada, já que existente menor risco na operação, diminuindo o deságio na mesma. Ademais, os membros do grupo contarão com uma padronização na gestão financeira de seus ativos, podendo liquidar antecipadamente seus recebíveis.

\section{REFERÊNCIAS}

ABREU, J. M. Coutinho de; MARTINS, Alexandre Soveral. Grupos de sociedades: aquisições tendentes ao domínio total, Editora Almedina, Coimbra, 2003.

ANTUNES, José A. Engrácia. A aquisição tendente ao domínio total, Coimbra Editora, Coimbra, 2001.

ANTUNES, José A. Engrácia. A supervisão consolidada dos grupos financeiros, Publicações Universidade Católica, Porto, Portugal, 2000.

ANTUNES, José A. Engrácia. Os grupos de sociedades - estrutura e organização jurídica da empresa plurissocietária, Editora Almedina, Coimbra,1993.

ANTUNES, José A. Engrácia. Participações qualificadas e domínio conjunto, Publicações
Universidade Católica, Porto, Portugal, 2000.

BARBIER, Eduardo Antonio. Contratación bancaria, volume 2 - Empresas, $2^{\mathrm{a}}$ ed, Editora Astrea, Buenos Aires, 2007.

BORGES, João Eunápio. Curso de Direito Comercial Terrestre, vl.1, Editora Forense, Rio de Janeiro, 1959.

BROSETA PONT, Manuel. Manual de derecho mercantil, décima edición, Editorial Tecnos, Madrid, 2000.

BULGARELLI, Waldirio. Normas Jurídicas Empresariais, Editora Atlas, São Paulo, 1992.

CARVALHO, Orlando de. Critério e Estrutura do Estabelecimento Comercial, Coimbra Editora, Coimbra, Portugal, 1967.

CHULIÁ VICENT, Eduardo e BELTRÁN ALANDETE, Teresa. Aspectos jurídicos de los contratos atípicos, Vl. I, segunda edición, JMB Editor, Barcelona, 1994.

FERRAZ, Daniel Amin. A concentração empresarial no contexto da economia internacional, em: FERRAZ, Daniel Amin. Direito Empresarial: marco jurídico de internacionalização das empresas brasileiras, Ed. CRV, Curitiba, 2012.

FERRAZ, Daniel Amin. Acordos horizontais, acordos verticais e a jurisprudência norteamericana e europeia sobre a matéria. Revista de Direito Internacional, Brasília, v. 9, n. 2, jul./dez. 2012.

FERRAZ, Daniel Amin. Dos contratos internacionais do comércio: regime geral, em: FERRAZ, Daniel Amin. Contratação internacional: algumas espécies de contratos mercantis, Editora CRV, Curitiba, 2015.

FERRAZ, Daniel Amin. Grupo de sociedades: instrumento jurídico de Organização da empresa plurissocietária, in: Revista de Direito Internacional, Volume 12, n 2, 2014, Brasília.

FERRAZ, Daniel Amin. La competência en el marco de los acuerdos horizontales y verticales: un análisis comparado de la UE, los EE.UU., Mercosur y Brasil, em: Papeles del Centro de Investigaciones, Universidad Nacional del Litoral, 
Santa Fé, Argentina, 2012.

FERRAZ, Daniel Amin. O grupo de sociedades: mecanismo de inserção da empresa transnacional na nova ordem econômica internacional, in: Revista de Direito Internacional, Brasília, v.9, n.1, jan./jun. 2012.

FERREIRA, Waldemar Martins. Tratado de Direito Mercantil Brasileiro, vl. 2, Livraria Editora Freitas Bastos, Rio de Janeiro, 1939.

GALGANO, Francesco. La globalizzazione nello specchio del diritto, Società editrice il Mulino, Bologna, 2005.

GOMES, Orlando. Contratos, $15^{a}$ edição, Editora Forense, Rio de Janeiro, 1995.

GONZÁLEZ NIEVES, Isabel Cristina. Estudios de Derecho y Economía, Editorial Heliasta, 2008.

HERNÁNDEZ MARTí, J. Contratación internacional, $2^{\mathrm{a}}$ edición, tirant lo blllanch, Valéncia, 1999.

LÓPEZ TILLI, Alejandro. Financiamiento de la empresa, Editorial Astrea, Buenos Aires, 2010.

MARTINS, Fran. Contratos e obrigações comerciais, $16^{\text {a }}$ edição, Forense, Rio de Janeiro, 2010 .

MENDONÇA, João Xavier Carvalho de. Tratado de Direito Comercial Brasileiro, vl. 1, 6a Edição, Livraria Freitas Bastos, Rio de Janeiro, 1957.

OLIVENCIA RUIZ, Manuel. Derecho mercantil y derecho de la empresa, em: JIMÉNEZ SÁNCHEZ, Guillermo J. Derecho mercantil I, Marcial Pons, Barcelona, 2010.

OSÓRIO, José Diogo Horta. Da tomada do controlo de sociedades (takeovers) por leveraged buy-out e sua harmonização com o Direito Português, Editora Almedina, Coimbra, 2001.
PALAO MORENO, Guillermo. Os grupos de empresas multinacionales y el contrato individual de trabajo, Tirant lo Blnch, Valencia, 2000.

PALMA, Augusta Ferreira. Das pequenas e médias empresas: algumas questões (máxime, no Direito da Concorrência), Editora Almedina, Coimbra, 2001.

PEGO, José Paulo Fernandes Mariano. A posição dominante relativa no Direito da Concorrência, Editora Almedina, Coimbra, 2001.

RIZZARDO, Arnaldo. Factoring, $2^{\text {a }}$ edição, Editora Revista dos Tribunais, São Paulo, 2000.

RODRIGUEZ RODRIGO, Juliana. Contratos internacionales de factoring, em: CALVO CARAVACA, Alfonso Luis e CARRASCOSA GONZÁLEZ, Javier. Curso de Contratación Internacional, $2^{\mathrm{a}}$ edición, Colex, Madrid, 2006.

SÁNCHEZ LORENZO, Sixto A. El Derecho inglés y los contratos internacionales, Tirant lo Blanch, Valencia, 2013.

SOARES, Marcelo Negri. Contrato de factoring, Saraiva, São Paulo, 2010.

TOMAZATTE, Marlon, Curso de direito empresarial: teoria geral e societário, volume $1,6^{a}$ edição, Atlas, São Paulo, 2014.

VAMPRÉ, Spencer. Tratado Elementar de Direito Commercial, vl.1, F. Briguiet \& Cia, Rio de Janeiro, 1922.

VARELA, João de Matos Antunes. Das obrigações em geral, vol. I, $8^{a}$ edição, Almedina, Coimbra, 1994.

VASCONCELOS, Pedro Pais de. Contratos atípicos, coleção teses, Livraria Almedina, Coimbra, 1995. 
Para publicar na Revista de Direito Internacional, acesse o endereço eletrônico www.rdi.uniceub.br ou www.brazilianjournal.org.

Observe as normas de publicação, para facilitar e agilizar o trabalho de edição. 